\title{
The Islamic economy: its origin, its world view and its claims
}

\section{Hans VISSER \\ Vrije Universiteit Amsterdam, The Netherlands}

\begin{abstract}
:
Aim: This article takes a critical look at the claims made by advocates of an Islamic economy, in particular that it differs fundamentally from capitalism and socialism because it is built "on a superior ethical basis. The aim is to find out whether this claim can be creditably sustained and why it is made.
\end{abstract}

Design: The world view behind the Islamic economy is probed into by means of a literature study encompassing publications by prominent students of Islam and Islamic economics, predominantly themselves Muslims, which have appeared in a wide range of professional books, magazines and paper series.

Conclusions: It is concluded that an Islamic economic system does not differ fundamentally from mixed-economy non-Islamic ones and that there is little reason for non-Muslims to accord Islamic ethics special status. Further, it is found that important drivers of the attempts to Islamize the economy are frustration about the sorrow state of the Islamic world at least since the early nineteenth century and a wish to regain something of its former glory. In other words, identity politics is at play. There may an element of subjectivity in this conclusion, as it depends on interpretations that are hard to prove or disprove conclusively, but statements by leading Muslim advocates of Islam economists give it weight. The conclusion may help to interpret developments in the Muslim world, which is an indispensable step in finding a way to deal with them.

Key words: Relation of Economics to Social Values, History of Economic Thought since 1925, Financial Economics, Monetary Systems, Financial Institutions and Services, Comparative Financial Markets and Institutions, Comparative Economic Systems, Religion)

JEL: A13, B26, E42, G20, N20, P50, Z12

Correspondence address: Hans VISSER Ph.D., Professor Emeritus of Monetary Economics, School of Business and Economics, Vrije Universiteit Amsterdam, The Netherlands. E-mail: h.visser@vu.nl Received: 13.09.2018, Revised: 30.10.2019, Accepted: 24.11.2019

doi: http://dx.doi.org/ 10.29015/cerem.765 


\section{Introduction}

Advocates of Islamic finance and of other forms of an Islamic economy claim that the Islamic economy is a system that is fundamentally different from other systems, being based on an ethical basis that is lacking in other systems. In order to find out why this claim is made and whether there is supporting evidence, the world view behind the Islamic economy is probed into: how do the advocates of the Islamic economy look at the world and the role or the duty of Muslims in it. We start with an account of the genesis of the idea of an Islamic economy that led to the foundation of specifically Islamic financial institutions. This is followed by a sketch of the worldview behind the Islamic economy and this world view is confronted with conventional capitalism. Next, the standard check list of Islamic economic ethics, a major ingredient of the Islamic world view, is discussed. Then I point to two issues where the Islamic economy, and again Islamic finance in particular, has some catching up to do, namely environmental, social and governance issues (ESG) and income distribution, and the article wraps up with a confrontation between the professed ethics and the real world of the Islamic economy and an attempt to find the driving motives behind the Islamic world view. The tone may be quite critical at times, but I have no axe to grind and my critique is to a large extent shared by Muslim observers of the Islamic economy, in particular the Islamic financial landscape.

\section{The genesis of the Islamic economy}

In the heyday of the Abbasid caliphate (750-1258) Baghdad became a flourishing centre of science, philosophy and invention. This ended with the sacking of Baghdad by Mongol forces in 1258, but its intellectual pre-eminence had already been eroding. One important factor was that less and less room was available for ijtihad, independent judicial reasoning by a qualified legal scholar leading to new legal rules. Ijtihad is one of the secondary sources of Islamic jurisprudence or fiqh; the Quran and the Hadith, that is the acts and utterances of the prophet Muhammad, 


\section{THE ISLAMIC ECONOMY}

being the primary sources. Ijtihad was widely applied in deciding what was admissible and what not when new products were developed, new kinds of trade relations developed, new political organizations arose, new inventions were made, new medical techniques were developed and so on. It made for flexibility and easy acceptance of change in society. However, fiqh scholars from the ninth century onwards increasingly argued that all important questions had been settled and that the then existing fiqh body was sufficient to answer all questions (Schacht 1982: 70; Hallaq 1984; Ebrahim, Sheikh 2018). Measures taken by the founder of the Mamluk sultanate of Egypt, al-Malik al-Zahir Baybars, who had made the Mamluks the dominant force in the Islamic Middle East after the demise of the Abbasid caliphate, accelerated this process. In 1265 he appointed one supreme judge for each of the four great Sunni law schools in order to bring some uniformity and predictability in jurisdiction, which he felt was necessary for strong centralized government. He furthermore required all judges to stick to the doctrine of the law school to which they belonged and follow judgements of earlier law scholars from their own school, rather than apply ijtihad. Baybars imposed this system first in Cairo and next in Damascus (Allan 2019). Also in the thirteenth century, the Islamic world was confronted by the Reconquista, the conquering of Islamic-held territory in the Iberian peninsula by Christian kingdoms, and by the Mongol invasion. There was a feeling that God had withdrawn his favour from Muslims and that to win it back Muslims had to follow the divine laws without questioning. There was no longer a place for rationalism, doubt had to replaced by certainty (de Bellaigue 2018: xxxv) By the fourteenth century it was agreed among the fiqh scholars, in Sunni Islam at least, that there was no place any longer for ijtihad and that 'the gate of ijtihad' had closed (Egger 2018: 63-64). This meant that intellectual curiosity was frowned upon, as it could easily lead to fitna, that is schism, social unrest, seditious dissent, civil war.

The Renaissance that transformed Europe between the fourteenth century and the seventeenth century left the Islamic world thus largely untouched and 'largely' became 'totally' when the Ottoman political and religious leaders, horrified when they saw how Martin Luther's attacks on the abuses of the Roman Catholic church went viral thanks to the printing press, took care not to let anything similar happen 
in their empire (Rubin 2017: chapter 6). There was no lively public debate, no exchange of new ideas over large areas, no empirical experimentation, no setting up of scientific organizations such as the Royal Society (1660) in England, no press disseminating news and trade information, no development of new machinery, such as James Hargreaves's spinning Jenny and James Watt's steam engine, no advance in medical knowledge, such as the development of the smallpox vaccine by Edward Jenner in 1796, and no chemical science as for instance developed by Robert Boyle and Joseph Louis Gay-Lussac. Nothing of this kind was remotely possible in the Islamic world under the fierce opposition of the ulama, the religious scholars, whether or not hand in glove with the worldly rulers, against any innovation and with the abysmally low prevailing literacy rates. In the early nineteenth century literacy in the Ottoman empire is reported to have been no more than two or three per cent, whereas in England and the Dutch Republic it was already over 50 per cent by 1700 (Rubin 2017: 107, 198).

In the nineteenth century the Islamic world was rudely confronted with the fact that European countries were far ahead in science, education, medicine, transport, military organization, industry and communication and that the gap was widening rapidly. Strongmen such as Muhammad Ali Pasha, who ruled Egypt (formally as Ottoman viceroy) from 1805 to 1849 , and Mahmud II, who reigned as the Ottoman sultan from 1808 to 1839 , enforced modernization, ruthlessly suppressing all opposition (de Bellaigue 2018). Islam played no role whatsoever in the achievements of nineteenth-century progress and Europeans, joined by intellectuals from the Islamic world, saw it as an obscurantist remnant. There were, however, Muslims who agreed that Islam had become fossilized but reacted by preaching a much more liberal form of Islam than what had become the mainstream. One man who stood out was Jamal al-Din al-Afghani (1839-1897). As European countries became more openly imperialist in the Middle East and Northern Africa as the nineteenth century wore on - Tunisia for instance became a French colony in 1881 and Britain took control of Egypt in 1882, while the French had already taken over Algeria in 1830 - aversion to European influence grew (India, Ceylon and the Dutch East Indies had been colonized earlier). Building on this aversion he inspired a panIslamist movement that united the Muslim world against European imperialism. 


\section{THE ISLAMIC ECONOMY}

This was possible thanks to much better communication as travel became ever easier, education improved and the printing press at last became common in the Islamic world, offering a propagation mechanism for revolutionary ideas as it had done more than three centuries earlier in Western Europe for Martin Luther's denouncement of the Roman Catholic Church's malpractices. In 1899 al-Afghani's pupil Muhammad Abduh (1849-1905) was named Grand Mufti of Egypt, the highest authority on Islamic jurisprudence and the head of Egypt's religious law courts, by the khedive (Ottoman viceroy; a mufti is an Islamic lawyer who is authorized to issue a fatwa, or legal opinion). Abduh shook up al-Azhar University, introducing secular subjects and modern sanitary conditions, and he propagated an enlightened Islam that no longer denied a place for human reasoning, thus reviving ijtihad. $\mathrm{He}$ even maintained that the Quran, the holy scripture of Islam, could be interpreted differently according to time and place and that it might contain errors, introduced by humans. This was, and is, anathema to mainstream Muslims and met with fierce opposition. Instrumental in spreading his ideas was Muhammad Rashid Rida (18651935), who published a journal, al-Manar (The Beacon), to which Abduh contributed legal rulings and reformist essays (Hashmi 2004a, c; de Bellaigue 2018: chapter 5).

The First World War and the resulting break-up of the Ottoman empire put an end to pan-Islamism and liberal reformist currents gave way to movements that attempted to make an alleged 'pure' Islam, not tainted by liberal secular notions, fit for governing life in the twentieth century. An important role was played by the Muslim Brotherhood in Egypt, founded in 1928 by Hassan al-Banna (1906-1949). Similar movements sprang up in other parts of the world with a large Muslim population. Muslim intellectuals in British India and, after the 1947 Partition, in Pakistan distinguished themselves specifically by developing ideas on how to organize the economy of an Islamic society. A pioneering role was played by Maulana or Mawlana Sayyid Abu'l-A'la Maududi (1903-1979), the founder of the Islamist Jamaat e-Islami party ('maulana' or 'mawlana', literally 'our master', is an honorific title for religious Muslim scholars in South Asia). Maududi (also spelled Mawdudi or Maudoodi) wrote, as editor of a journal he founded in 1932 for Muslims in British India: "The plan of action I had in mind was that I should first 
break the hold which Western culture and ideas had come to acquire over the Muslim intelligentsia, and to instil in them the fact that Islam has a code of life of its own, its own culture, its own political and economic systems and a philosophy and an educational system which are all superior to anything that Western civilization could offer. I wanted to rid them of the wrong notion that they needed to borrow from others in the matter of culture and civilization" (quoted in Slomp 2003: 240). The economic system thus figured explicitly in his plans for an Islamic revival (Kuran 2004: chapter 4). After delivering an address on the subject in 1941 (Maududi 1941/1999), he went into more detail in several works on the principles that should govern an Islamic state (Maududi 1963, 1999). Others in India and later in Pakistan followed in his footsteps, in particular Anwar Iqbal Qureshi in 1946 (Qureshi 1946), Naiem Siddiqhi in 1948 and Mahmud Ahmad in 1952 (see Gafoor 1996: 37; Mahmud Ahmad 1999). In Egypt a prominent exponent of one of the more radical wings of the Muslim Brotherhood, Sayyid Qutb (1906-1966), wrote on the characteristics of an Islamic society, though without going into detail specifically on the economy, as Maududi had done (Hashmi 2004b). Qutb emphasized the idea of social justice in Islam (Qutb 2000; Damir-Geilsdorf 2018). He also preached violent action, first of all against leaders of Muslim countries who were seen to betray Islam.

The ideas of these, and other, Islamic reformists paved the way for the establishment of Islamic financial institutions, which after some earlier small-scale experiments took off in the 1970s, when the oil states were awash with liquidity thanks to the oil crises. After a meeting of the foreign ministers of Islamic countries in Jeddah to discuss Islamic banking, the Nasser Social Bank of Egypt was set up in 1971 with government support. It mainly provided qard hasan loans (interest-free loans against at best a very low administrative fee) to the poor and the needy, scholarships to students and micro-credit to small projects on a profit-and-loss sharing (PLS) basis (Abedifar et al. 2015). Another such meeting in late 1973 led to the foundation of the Islamic Development Bank (IDB) in 1974, which owed very much to the initiative of Egypt and Pakistan, arguably the cradles of twentiethcentury Islamic banking. It went open for business in 1975 and first helped oilimporting countries cope with the oil crisis by buying oil and selling it to them on a 
murabaha basis. Murabaha involves the purchase by a party, often a financier, of a good desired by another party, often the financier's client. The financier sells the good on to the client with a markup, usually against deferred payment. The oilproducing Gulf states provided most of IDB's initial capital, as it was in their interest to sell oil to other Muslim-majority states and promptly be paid the full market price, without the resentment that balance-of-payment crises might otherwise cause in the importing countries (Wilson 2008). Private banking following Islamic principles also started in 1975, with the foundation of the Dubai Islamic Bank by a group of pious merchants (though with the governments of the UAE and Kuwait contributing respectively 20 percent and 10 per cent of the capital), followed by the Faisal Islamic Bank in Egypt and Sudan in 1977.

In other sectors of the economy there had always been segments catering for the needs of pious Muslims, but following the lead of the finance industry we are now witnessing an increasingly internationally active Islamic 'modest clothing' industry for women, a specialized Islamic travel industry, an Islamic pharmaceuticals industry, an Islamic cosmetics industry and an Islamic media and recreation industry (see Thomson Reuters 2017). In this way the post-World War I reformers' ideal of an Islamic economy is more and more taking shape, though they would perhaps not approve of the direction Islamic finance has taken. It is often seen as conventional banking made more complicated, not without some justification.

\section{World view behind the Islamic economy and a critique}

Now what are the distinguishing features of an Islamic economy? In the view of the likes of Maududi and Qutb and also more recent proponents of a specifically Islamic organization of the economy, Islam is fundamentally different from capitalism and communism. The latter two lack, in their view, a moral code. Capitalism lets individuals pursue their selfish ends without regard for the needs of others while communism imposes unacceptable restrictions to individual liberties and opportunities for self-fulfilment. Proponents of Islamic finance make much of 
this moral code. This is a central notion of Islam: sharia is God's universal moral law and both legal and moral laws ideally flow from it.

As communism is no serious player at the moment, we will focus on the alleged superiority of the Islamic economy, and in particular Islamic finance, over capitalism. First, the presumed contrast between Islam and capitalism is highly questionable. Capitalism is often equated with Anglo-American free-market neoliberalism where huge firms have free play. However, insofar this really exists (the US is far from a free market) it is only one historical form of capitalism among many. Capitalism can be denoted as a way of organizing production. Capitalism is a system characterized by private ownership of the means of production (note that other definitions of capitalism are possible, see for a dazzling multitude of possible connotations Rodinson 2014: chapter I). Capitalism in this definition is not synonymous with a free market economy. Capitalism can exist in highly regulated societies, such as Nazi Germany, and on the other hand non-capitalist organizational forms can exist and even flower in more or less free market economies, think of cooperatives and the former Yugoslav communist market economy with workers' self-management. Now Islamic economies arguably are, like most other economies, mixed economies with both private firms and government production of goods and services. The Islamic version distinguishes itself by an explicit moral code, said to be derived from divine law. A prominent feature of this moral code in economic life are the bans on riba, gharar and maysir, and on haram goods such as pork, alcohol and adult entertainment. What are these for? One of the most prominent scholars of Islamic finance, Professor M. Kabir Hassan of the University of New Orleans (Hassan 2017: 1) says:

Islamic finance is built on a foundation of socioeconomic justice for all and sustainable growth facilitated by prudent stewardship of natural resources so that future generations may also enjoy the fruits of economic development.

In the same vein, Dr Asad Zaman (Zaman 2015: 13), the Vice-Chancellor of the Pakistan Institute of Development Studies, maintains that 
Since the spirit of Islam is in stark and violent conflict with the spirit of Capitalism, the form taken by institutions designed to express this spirit must also be different. Capitalist financial institutions are designed to support the process of accumulation of wealth, which is at the heart of capitalist societies. Central to Islam is the spirit of service, and spending on others, which is expressed by diverse, service-oriented institutions, radically different from those dominant in capitalist societies.

These are far from modest claims, repeated in numerous publications (another influential one is a book by the prominent Muslim Brother Yusuf al-Qaradawi, 2010). What is behind it? The 'Thou shalt nots' of the various bans may give a negative impression: you shouldn't do this and you shouldn't do that, but they have a positive purpose, namely to fulfil the maqasid al-shariah or goals, higher objectives, of Islamic law. These should bring about the socioeconomic justice mentioned by Hassan and already emphasized by Hassan al-Banna. There is a strong tendency among writers on Islamic finance and the Islamic economy in general to follow medieval scholars, and in this case the great philosopher Al-Ghazali (c.10581111), who defined the maqasid al-sharia as safeguarding

(a) people's religion, broadly defined as their way of life

(b) their life or soul

(c) their family or offspring

(d) their property or wealth

(e) their intellect or reason, also interpreted as their dignity.

These serve to promote their welfare or maslaha, the goodness of this life and the hereafter (Ghazanfar, Islahi 1990; 2011). However, one may wonder whether these norms are really that unique and insofar they are, to what degree they are reflected in day-to-day behaviour. The higher objectives certainly are not unique. Then why all the fuss? An answer can be found in another quote from M. Kabir Hassan (Hassan 2017: 2):

Islamic economics and finance is gaining traction because much of the Muslim world wants to relive long-gone times when Islam was the dominant force driving 
world history. Muslims believe they have a responsibility to extend the message of Allah's final messenger to all humanity. (...) Now that Muslim states are politically free from their colonizers, they are seeking to cultivate their own home-grown, Islam-based systems of knowledge. Islamic economics and finance is part of this.

And here we may have Des Pudels Kern, the gist of the matter: the Islamic economy or Islamic economics serves to throw off the frustration that drove the Islamic reformers at the end of the nineteenth century and in the twentieth century. Imagine: Islam claims to be the final, perfect religion, after Jews and Christians allegedly corrupted God's revelation (see for instance Quran, Sura 5). It swept everything before it. In an astonishingly short time the armies of Islam conquered the Middle East, North Africa and most of the Iberian peninsula and in 732 or 733, only one century after the death of the prophet Muhammad, they had progressed as far as the region between Tours and Poitiers, where their push was halted by Frankish and Burgundian forces under Charles Martel. The cities of the Islamic world became centres of intellectual life and scholarship without equal in the whole of Europe. If it is so superior, how then is it possible that in the nineteenth century the Islamic world had become a mere shadow of its former self? That of course was hard to swallow. The Islamic economy then is one means for the umma, the global community of Muslims, to reassert itself (see on the concept of umma Widhiyoga 2019). And that is indeed what an overwhelming majority of Islamic religious leaders find to applaud in Islamic finance, according to enquiries (Khan, Bhatti 2018).

Let us now go back to the claim that capitalism lacks a moral code, or an ethics. It is by no means only Muslims that condemn capitalism for encouraging greed, selfishness and corruption but also communists, socialists of all stripes and church leaders, think of the encyclical Rerum Novarum issued by pope Leo XIII in 1891, the encyclical Quadragesimo anno issued in 1931 by pope Pius XI and the almost ritual condemnation of capitalism by the World Council of Churches. Now it may be true that capitalism has an orientation to the accumulation of wealth and too often gives free play to unsavoury characters, but first you have to wear blinkers not to see 


\section{THE ISLAMIC ECONOMY}

the same in the Islamic variant of capitalism, and second, the greed for gain is not the exclusive province of capitalists. Political power corrupts at least to the same degree, if not more. Both the power of capitalists and the power of political elites need to be held in check by countervailing power (Galbraith 1963). A very important and effective form of countervailing power is civil society with its factfinding by NGOs and the media and this flourishes best in mixed-economy parliamentary democracies (though even there NGOs and the media face harassment, see "The Economist" 2019). The Islamic world, certainly in the Gulf region, too often does not allow civic society to flourish,

Capitalism is a structure for organizing the economy. If it is embedded in a market economy it is based on the notion that decentralized ownership and decisionmaking makes the best use of human creative powers and helps to prevent centralizing too much power in the hands of the government, but that is not different in Islam. There is nothing in Islam that inherently is inimical to capitalism (Rodinson 2014), indeed, the first wife of the Prophet, Khadija, was a capitalist entrepreneur and he himself was one of her employees for a number of years. Over and above this basic foundation, capitalist market economies can harbour various ethical rules. These need not necessarily come from religion, though of course religions are extremely influential producers of ethical rules (and enforcers of rules of behaviour preferred by religious elites). Ethical rules can also be produced by nationalistic and political movements, such as communism and fascism (ethical rules or systems are not by definition always pleasant). A very important source of ethical rules is action by NGOs. Changing views on racism, homosexuality, corporate social responsibility, accountability of government, conservation of nature and animal rights have to a large extent been initiated by NGOs, and not by organized religion, often even against the opposition of organized religion or religious groups. Ethical rules can furthermore result out of confrontations between interest groups, for instance employers and employees, leading to changing views on labour rights and stakeholdership. Capitalism thus need not necessarily have the maximization of profits and shareholder value as its overriding objective. And whatever the defects of capitalism, it is the only system that fully makes use of the entrepreneurial qualities and the innovate power of the people. Karl Marx and 
Friedrich Engels, who expected capitalism to collapse under its own contradictions, still talked about bourgeois capitalism as a system that had conjured up most impressive means of production and transport (“... die modern bürgerliche Gesellschaft, die so gewaltige Produktions- und Verkehrsmittel hervorgezaubert hat"; Marx, Engels 1890/1974). Some Muslim scholars who want to emphasize the uniqueness of Islam claim that Islam has a different epistemology than the capitalist world. They are not impressed by the productive powers so admired by Marx and Engels and flatly deny that there is any scarcity of resources. This is because "The Qur'an states that Allah has provided an abundance of everything that humankind needs in order to subsist" (Golestani 2018; in the same vein Cattelan 2018). If there is scarcity, that is because of limitations of mankind's productive capacity, not of a lack of resources. The Islamic economy knows no scarcity, thanks to the ethical values of Islam. The well-off do not strive for ever more income and wealth and the less-well-off receive everything they need. An ideal somewhat removed from reality.

Capitalism leaves room for various ethical systems, including Islamic ethics, and these systems are not mutually exclusive. Further, neither Islam nor any other religion can claim moral superiority. In the financial sector a case in point is Triodos Bank. Triodos Bank is a Dutch ethical bank that specializes in financing sustainable business. Khan and Mohomed (2017) confront Triodos Bank with Islami Bank Bangladesh Limited (IBBL), which they deem an ideal Islamic bank as it probably far exceeds other Islamic banks, in their words, "in terms of financial inclusion, microfinance, gender balance, SME financing and green banking while still being financially stable and profitable" (Khan, Mohomed 2017: 111). After a careful analysis of the banks' business practices they conclude that Triodos Bank "has some significant lead over IBBL regarding ethical practices," and if Triodos Bank exceeds IBBL with regard to ethical practices "then it is far ahead of other Islamic banks in such comparison". ${ }^{1}$

\footnotetext{
${ }^{1}$ Islami Bank Bangladesh has since lost its lustre. In 2017 the government forced senior executives and board members of Islami Bank to resign because of the bank's links with the Islamist Jamaat-e-Islami party. In 2018 another purge followed. The new management has not maintained Islami Bank's former high standards and just like in government-owned banks loans now often are granted to people with political connections, who have a poor track record when its comes to paying back their loans. The central bank of Bangladesh found many irregularities and breaches of financial regulations in Islami
} 
There is little reason for self-congratulation for Islamic banks. Islamic finance is not of a completely different moral character than conventional finance. Indeed, it is a common complaint among Islamic observers that Islamic finance in practice comes down to mimicking the operations and products of conventional banking while nominally observing Islamic rules (e.g., El-Gamal 2006: 65, 138, 163; Asutay 2012; Ayub 2017). It often boils down to ticking off boxes on a standard check list. In the other sectors of the Islamic economy things may be more clear-cut, but there too business practices will not differ much from conventional capitalist ones.

\section{The standard check list of Islamic economic ethics}

The Islamic economy wants to obey the injunctions of Islamic religious law. But while orthodox Jews would be content to follow God's commandments and not necessarily understand what they are good for, the proponents of the Islamic economy strongly believe that the Islamic rules are beneficial for mankind (Alwani 2016). The maqasid al-sharia reflect these claims. Let us now look how the three items on the standard check list of Islamic finance ethics score in this respect. These items are:

(a) the ban on riba

(b) the ban on gharar and maysir,

(c) the ban on haram goods and services

(a) the ban on riba

A central plank in Islamic finance's platform is the ban on interest. It is a moot point whether riba can really be equated with interest, but dissenters are few and far between (Suharto 2018). One form of riba concerned a pre-Islamic Arabic custom. If a debt was not paid on maturity (after one year), the principal was doubled, according to most commentators (for instance, Fazlur Rahman 1964; Qureshi 1991:

Bank's loans (The government initiates a coup at Bangladesh's biggest bank, "The Economist", 6 April 2017, Islami Bank Bangladesh has declined since a boardroom coup in 2017, "The Economist", 6 April 2019). Jamaat-e-Islami was allied with the Bangladesh Nationalist Party, whose leader Khaleda Zia is the arch-foe of Sheikh Hasina Wajed, the prime minister and leader of the ruling Awami League. 
54). Quran 3:130, which admonishes the believers not to devour "usury, doubled and multiplied," most probably refers to this custom. The ban on riba was aimed, in the view of some commentators, at preventing the debtor getting enslaved. That would make the ban on riba from the Quran irrelevant for present-day banking and finance, as it would only bear on riba al-jahiliyya, the riba practised by the Arabs in the pre-Muslim "time of ignorance" (Rahman 1964; Kuran 1995: 156-157; R. Zaman 2011; El-Gamal 2019: 114-115). Nevertheless, fiqh scholars are adamant that riba includes interest.

The deleterious effects of interest are extensively discussed in the Islamic literature. Interest makes the wealthy even more wealthy while they put no effort in it and it leads to exploitation of the weak, the borrower, by the strong, the lender. It is also averred that interest contributes to gambling with other people's money (see Hassan 2017). This is the standard view, but it is a flawed one. First, it is not all true that the lender is always the strong party and the borrower the weak one. If you hold a time or savings deposit at a bank, the only power you have is to switch to another bank and one cannot reasonably claim that the depositors exploit the bank. Depositors have at best very weak power to dictate rates. Second, a very large part of savings is in the form of collective savings. Fixed-income securities are predominantly owned by pension funds and insurance companies. Pension plans that invest in fixed-income securities are not known as seriously increasing income disparities. Even abstracting from the low interest rates of the last decade or so, it can be maintained that interest as a cause of income and wealth disparities pales into insignificance alongside successful business ventures, grossly unequal pay, the rise of the gig economy, unequal access to education, political clout of the rich (which translates into low effective tax rates for the rich), tax evasion, cronyism, bribery, restrictions of market access in order to create rents (think of the vast business empires of the Egyptian army and the Iranian Revolutionary Guard) and other shady dealings. What remains true is that borrowing against interest may result in gambling, or in very risky balance sheet ratios. Credit, including borrowing money (as distinct from buying against deferred payment), is an excellent means to help a business and individuals increase their opportunities, but it may easily get out of hand. The solution, however, is not to condemn debt per se, but to stop giving debt 


\section{THE ISLAMIC ECONOMY}

favourable tax treatment, in other words to reduce or phase out tax deductibility of interest. Limits to loan-to-value ratios in mortgage finance can also help. The point is that interest-bearing debt is a useful tool in the financial instrument box, but that it should not be used excessively, in common with so much in human activities. Riba is equated with interest, but it has the connotation of excess, unearned income, a rent. Farooq $(2012,2019)$ argues that the fixation on interest has led to the neglect of many kinds of unjustified and unjust enrichment, including monopolies, rentseeking lobbying and rewarding contracts to privileged parties. The proponents of a separate Islamic epistemology tend to be blind to it. Golestani (2018) sees riba as one of the worst instruments of exploitation of human beings by other human beings and claims that it has been abolished root and branch by Islam. Quod non, see below, and rent seeking by sheltered or favoured firms also stays out of his purview (though he mentions bribery).

The Islamic condemnation of interest is mistaken. Another question is whether the Islamic alternatives are fundamentally different. Interest on money loans is forbidden in Islamic finance. However, they fulfil a very useful role and the business community cannot easily do without. Islamic business firms cannot do without either, however much fiqh scholars would like to see debt replaced by profit-andloss sharing arrangements. Profit-and-loss sharing (musharaka) and profit sharing (mudaraba) arrangements are, however, beset with information and moral-hazard problems and are not very popular (see Visser 2019: 71-75). Buying goods on credit is allowed, but cannot fully fulfil the needs of Islamic business firms. The Islamic financial sector therefore takes recourse to hiyal, that is, legal fictions, tricks. A very popular Islamic contract for instance is tawarruq. In a tawarruq a financier buys commodities and sells these to its customer against deferred payment. The customer sells the goods against cash, or asks the financier to sell them as its agent. Usually the goods are immediately sold on. The end result is a money loan. A tawarruq deal is made up of separate contracts which are individually halal, and as the contracts are not formally dependent on each other either (which would imply gharar or avoidable uncertainty and is not allowed in Islamic contract law), tawarruq cannot be labelled haram, or so the reasoning goes. Still, it obviously aims at getting a money loan or investing money against a predetermined fixed payment (Ayub, Paldi 
2015). Fiqh scholars of AAOIFI (Accounting and Auditing Organization for Islamic Financial Institutions) and the Fiqh Academy of the Organization of the Islamic Conference, two authoritative organizations that set standards for the Islamic finance industry, would love to reduce its use, but the need for it is overwhelming, not only among non-financial firms but also, in fact most of all, among the banks, which need it for cash management purposes (both for borrowing and investing funds). In the United Arab Emirates, Malaysia and Kuwait the central bank offers the commercial banks facilities for tawarruq-based short-term borrowing and investments (CBUAE 2010). With tawarruq it can truly be said that Islamic finance is conventional finance made more complicated. Tawarruq is extremely popular. According to Sohaib Umar of the Central Bank of Bahrain it is the most widely-used Islamic finance product in Malyasia and Saudi Arabia. Out of a global total of US\$1.7 trillion of outstanding Islamic financing in the mid-2010s some US\$750 to 800 billion was estimated to consist of tawarruq assets (Umar 2015).

(b) The ban on gharar and maysir

This ban sounds very innocuous and even sympathetic: there should not be any ambiguity or avoidable uncertainty in contracts, gharar, and you should not practice speculation, maysir. Now speculation is a slippery concept, it means trying to profit from intertemporal price differences, but in this wide definition a choice between renting and buying a home is also a question of speculation. If we interpret it in a narrower way as something like cornering the market and then charge extortionate prices, most people will probably agree it is despicable. Note that Tenach/the Old Testament also condemns it. Proverbs 11:26 says, in the King James version:

He that withholdeth corn, the people shall curse him: but blessing shall be upon the head of him that selleth it.

Or, in a modern translation:

Him who monopolises grain, the people curse - but blessings upon the head of him who distributes it! (New American Bible, United States Conference of Catholic Bishops, http://www.nccbuscc.org/nab/bible/proverbs/proverb11.htm) 


\section{THE ISLAMIC ECONOMY}

However, the ban on maysir is not completely innocuous; it has, jointly with the ban on gharar, a great impact on insurance activities for Muslims. Fiqh scholars see conventional insurance as tainted by both gharar and maysir. Gharar is involved because there is ambiguity in the contract: policy holders do not exactly know what they will receive in return - it may be nothing, it may be a million euros. It is also seen as gambling or speculation, maysir, if you pay your insurance premium and receive either nothing or much more than your accumulated premiums in return (Maududi 1999: 288). The conventional idea that you buy security is rejected. However, if you pay premiums to Islamic takaful or mutual insurance companies, you buy security in the same way as with a conventional insurance policy. Running a takaful firm is complicated and policy holders are not always well served (see Visser 2019: 151-155).

Another problem is that, as noted above, fiqh scholars consider contracts that are dependent on each other as guilty of gharar, because the fulfilment of one contract is a condition for the validity of the other, which introduces avoidable uncertainty with respect to the fulfilment of the contractual obligations. The result is that you have, for instance, first to make sure that finance is available before you buy a house, you cannot make a purchase conditional on finding finance as that would create ambiguity. Furthermore, it is very difficult to hedge risks, such as foreign exchange risks, first because conventional hedging products are interest-related, but second because Islamic variants have to circumvent the non-dependency rule. Hedging usually consists of more than one agreement combined in one contract. Recent solutions for this probems involve one-sided promises, wa'ds, but these do not provide the same level of legal certainty as a conventional derivative. Such wad's are also involved in ijara wa iqtina, hire-purchase (see Visser 2019: chapter 4, section 4.4.6).

(c) the ban on haram goods and services

Here we have the same phenomenon as noted above on interest: avoiding excesses is better than an outright ban. But Muslims have little choice if they take the bans in the Quran and the Hadith seriously, though it is not immediately obvious to non-Muslims that the Islamic ethics system is superior to other systems in this 
respect. This will be clear for instance if we look at the ban on many forms of entertainment. On this category the Quran and the Hadith are less clear than on other categories. Fiqh scholars restrict the choices people can make in varying degrees. Arguably people should be not be forced to live in a very narrowly restricted way, just to please a number of strict ulama and fiqh scholars who detest modernity. Moreover, vibrant city life with an innovation-oriented population is not possible if there is no room for experiments in all sectors of life, including entertainment. It is telling that when the strict Almoravids and after them Almohads took over Cordoba in 1090 respectively 1147, not only the Jewish philosopher Moses ben Maimon, or Maimonides, had to flee to Baghdad, but that the Almoravid burned al-Ghazali's manuscripts more than once (Garnier 2018: 102) and the Almohads expelled the great Islamic scholar Ibn Rushd, or Averroes. Puritanical masters kill freedom, fun and creativity.

\section{Areas of relative neglect}

The Islamic economy has lofty ideals but there is a large gap between those ideals and actual practice. Mimicking conventional finance while meeting a series of requirements in order to formally meet sharia norms does not lift an institution to a different ethical plane. Moreover, sticking to al-Ghazali's old list of maqasid alsharia has led to a lack of attention to a number of issues that in the present global situation are felt to be essential for people's wellbeing and the preservation of the planet, such as justice, human rights, universal education, accountability and transparency, environmental protection, animal rights and corporate social responsibilities. The Islamic world was confronted with the issue by outside pressure. It has been reported for instance that Australian cattle exports to Malaysia fell from over 50,000 head in 2015 to 21,330 in 2017, largely because Australian producers are not allowed to export cattle for ritual slaughter. This is because exporters are held responsible under Australian law for ensuring that the entire supply chain conforms to Australian standards, even after the cattle has left the country, and Australian authorities have grown increasingly critical of Malaysia's 


\section{THE ISLAMIC ECONOMY}

standards of animal welfare. Slaughter practices at religious festivals have been found espcially worrying and Australian producers were in 2018 not allowed to sell cattle, nor sheep and goats, to Malaysia for ritual slaughter. ${ }^{2}$ Another issue concerning the thought complex of the Islamic economy is income distribution. True, there are a few voices calling for including some of these items among the maqasid al-sharia, but so far they are a small minority (Khan 2016; Opwis 2017).

We now zoom in on two of the issues where the Islamic economy still has a lot of catching up to do: (a) ESG (Environmental, Social and Governance), (b) income distribution.

(a) ESG (Environmental, Social and Governance)

Under the ESG label we include CSR (Corporate Social Responsibility) and SRI (Socially Responsible Investment). In principle following the sharia should include everything encompassed by these notions, initiatives in these areas should thus be superfluous for Islamic financial institutions and Islamic organizations in general. It is argued, for instance, that "From an Islamic perspective, social responsibility exercised by a business organization is seen as a benefit, rather than as a cost (...) Individuals and businesses are encouraged to sacrifice, give and spend their wealth for the poor and needy, in view of the afterlife recognition. This sense of duty, responsibility, and spirit of sacrifice, nourished by the Islamic religion, serves to remove egocentrism and greed and to promote the compassion, care, cooperation and harmony of the community" (Litardi et al. 2019). There is much overlap with the conventional emphasis in corporate social responsibility on People, Planet and Profit, though, as Litardi et al. note, the Islamic approach includes a religious element. This includes fear of the consequences for the afterlife if God's commands are not obeyed (the concept of divine grace and forgiveness which figures prominently in Christianity and to which there are some parallels in Buddhist Pure Land schools is largely absent in Islam). As everywhere else, there is some divergence between principles and practice. Litari et al. note that there is very little evidence of a real practical commitment to implement CSR and to social reporting

\footnotetext{
${ }^{2}$ Eid al Adha festival of sacrifice heaps pressure on Malaysia to fix its livestock supply chain, www.salaamgateway.com, 22 August 2018.
} 
among large Arab companies. Khan and Usman (2016) studied vision statements, mission statements and annual reports of five Islamic banks in Pakistan and asked bank managers about CSR practices followed by these banks. It turned out that the banks paid attention to the needs of society and the community, while only two of the five banks mentioned the environment. The welfare of employees and customers was neglected. The authors did not investigate the actual practices of the banks, but a failure to mention an item in mission statements and annual reports is not a good omen. It has further been found that a couple of Islamic banks in Malaysia pay attention to the environmental impact of their offices, but that they generally do not consider environmental and social risks when approving financing. Subsidiaries of foreign banks usually are more environmentally conscious, thanks to their international shareholders (Kunhibava et al. 2018: 145-146). And while the Sustainable Development Goals of the UN are being addressed by a couple of banks in Malaysia and Indonesia, Islamic banks from the Gulf region were hardly interested (Thomson Reuters 2018: 29). San José and Cuesta (2019) note that Islamic finance is more focused on formal sharia compliance than on social and environmental goals.

Islamic financial institutions and their advocates emphasize their contribution to responsible finance, while tending to neglect such initiatives as the UN Global Compact. This is the more remarkable as the Islamic Development Bank and its private sector arm, the Islamic Corporation for the Development of the Private Sector (ICD), give their full support to the Sustainable Development Goals of the United Nations. Participants in the UN Global Compact commit themselves to obey a set of principles on human rights, labour, the environment and anti-corruption in their activities and to contribute to broader societal goals such as the UN Social Development Goals. The few Islamic firms among the 885 financial institutions that participated as per 1 September 2016 mainly belonged to groups that were not exclusively Islamic, based in non-Muslim-majority countries. ${ }^{3}$ Such initiatives as the UN Global Compact, the United Nations' Environment Programme Finance Initiative Principles for Responsible Banking (UNEP-FI) and the Dubai Declaration

\footnotetext{
3 'UN Global Compact lacks Islamic banking participation', IFN Alerts, islamicfinancenews@ redmoneygroup.com, 12 February 2016.
} 


\section{THE ISLAMIC ECONOMY}

of Financial Institutions in the UAE on Sustainable Finance also find a very lukewarm response from Islamic financial institutions. ${ }^{4}$

In the social sphere the record is not impressive either. Like their conventional peers from countries lacking critical monitoring by NGOs and groups of shareholders, Islamic financial institutions tend to pay no attention to labour conditions in the projects financed by them, even if these were reported to be extremely poor on the building sites in the Gulf countries Bahrain, Qatar and Dubai in which they were heavily involved (Leins 2010; Amnesty International 2013). The lot of foreign labour in the UAE seems to have improved somewhat by reforms introduced in 2011 and 2016 after fierce international criticism, by giving them somewhat more freedom to change jobs, but domestic workers remained helpless against misbehaving employers, and then the reforms only applied to the UAE where it is unclear what effect they have ("The Economist" 2016; Fanack 2018). Bad treatment of labour is clearly contrary to Islamic ethical principles, but there are no formal Islamic labour codes. The codes developed by the International Labour Organization (ILO) and the United Nations, however, seem to be fully in conformity with Islamic principles and could easily be adopted by governments of Islamicmajority countries (Reda 2016). In this area there is still a lot to do for them.

One area that has especially suffered from neglect was corporate governance. While standard ESG screening includes corporate governance, sharia screening of Islamic investment does not (Pathan 2016). For banks, it is far from universal. The European Corporate Governance Institute (ECGI) describes corporate governance as follows:

Corporate governance refers to the way in which private and public companies, enterprises, entrepreneurship and financial institutions are governed and run in relation to their purpose, values, ownership, representation, accountability, financing, investment, performance, leadership, direction, management, employment, law, regulation and taxation. ${ }^{5}$

\footnotetext{
${ }^{4}$ Dubai Declaration on sustainable finance welcomes first and only fully-fledged Islamic financial institution, IFN Alerts, islamicfinancenews@ redmoneygroup.com, 1 September 2017.

${ }^{5} \mathrm{http}: / /$ www.ecgi.global/content/about-ecgi [30.06.2018].
} 
The concept in this formulation includes a smorgasbord of issues, but it boils down to the question whether an organization is run decently, with "decently" having a different connotation for different groups of people in different regions and different times. Transparency and accountability can be seen as key elements in any definition.

The Islamic finance literature is fully aware of the fact that Islamic financial institutions often exhibit serious deficiencies in the area of corporate governance. Things are made more complex in Islamic finance than in conventional finance because of the former's peculiarities. For instance, holders of investment accounts in Islamic banks should periodically receive a part of the bank's profits, but the bank may decide to prevent low payments to investment account holders in lean years to prevent them defecting to competitors. This raises an agency problem, and thus to a corporate governance problem, as such payments go at the expense of profits left to shareholders. Then, investment account holders can only vote with their feet, but only after the investment has matured. They simply have to trust the bank managers to invest the funds such that the interests of the investors are best served. They run the same risks as shareholders, but unlike shareholders they have no voice in appointing managers nor can they withhold their approval of the annual accounts. Supervisors in a number of jurisdictions therefore allow deposit guarantees for investment accounts in order to limit the downward risks, which is at variance with the profit sharing or profit-and-loss sharing character of the Islamic investment funds. But already on a more basic level there are plenty of corporate governance problems. Sairally (2013) notes that the Islamic banks tend to restrict themselves to making sure that formal legal and sharia norms are observed and economic responsibilities are met. And even here they are often lax. Ayaz and Mansoori (2017) point to incompetent board members, moral hazard and sloppy risk management. All these elements became glaringly apparent in a notorious case of repeated fraud at Dubai Islamic Bank in the 1990s and early 2000s, when after fraud was detected the directors preferred a hush-hush approach over taking strong measures to prevent fraud in future (Mukmimin 2018). Even sharia compliance is not guaranteed. There are numeral voices in the Islamic world calling for taking corporate social responsibility more serious. Some authors think that Islamic ethics 


\section{THE ISLAMIC ECONOMY}

is the answer to all governance problems and that there is no need to look further. Zainuldin et al. (2018), after elaborating on the various governance problems in Islamic banks, blithely state that consultative consultation, that is allowing all stakeholders to contribute to the decision-making process, is the way to ensure that Islamic ethics rule the process so that everybody takes account of other peoples' interests and no dishonesty will occur. As Islamic ethics is based on presumed divine revelation, it is important to support any proposal with references to the prophet Muhammad and Zainuldin et al. argue that consultative (shuratic) decisionmaking characterized the leadership of the prophet and the caliphs (the worldly and spiritual leaders of the Muslim community) after him. In their view conventional agency theory neglects ethical stances, but their conclusion that "the Islamic ethical system incorporated in their business activities forms Islamic banks into organisations that place higher ethical considerations and therefore makes Islamic banks to have less severe agency problems compared to conventional banks" looks like wishful thinking dressed up as a fact. A sharia-based ethics would at the very least require something like a unified sharia governance framework, but it has been found, for instance, for Bangladesh that such a framework is lacking and that it is left to the banks how they apply the sharia principles. It is argued that this lax attitude by the banking supervisory authorities leads to poor accounting practices, financial products that do not fully comply with the sharia, questionable organization of the banks' shariah boards and lack of information for the stakeholders (Alam et al. 2019).

To end this section on a postive note, Islamic-majority countries, like the rest of the world, no longer shut their eyes for environmental problems and the depletion of natural resources. Projects for greening the economy are proliferating, especially in oil-exporting countries that have the funds and want to diversify the economy in time for the expected future run-down of oil and gas production, first of all the UAE. Islamic financial institutions have responded to this new awareness of environmental issues, stimulated by the Islamic Development Bank, and offer their services to issue green sukuk for that purpose. It is a market that started in the second half of the 2010s and promises fast growth (Soo 2017). Furthermore, Islamic ESG-oriented investment funds have slowly appeared over the 2010s, with Malaysia in the lead, 
again with the active support of the Islamic Development Bank. Furthermore, investors increasingly include corporate social responsibility in their investment criteria and investment funds have to respond to these requirements. There is thus a ready market for debt and equity that meet ESG principles. Islamic pension funds start to follow this trend. Also, central banks or Ministries of Finance are setting up central sharia boards that issue obligatory guidelines for Islamic financial institutions. Some examples are Indonesia, Kuwait, Lebanon, Malaysia, Oman, Pakistan, Sudan, Nigeria and the UAE; followed by the Central Bank of Iraq which announced in October 2019 that it is establishing a national sharia board.

All in all, it is probably fair to conclude that in the light of ESG and associated standards Islamic financial institutions cannot claim to play in another ethical league than conventional ones and even generally belong to the laggards.

(b). Income distribution

There is a strong emphasis in the fiqh on the need to provide the poor with sufficient income to survive in a relatively decent manner and preferably to supply them with the means to earn an income that enables them to meet their basic needs. Rising above that minimum is, however, generally seen as their own responsibility. This is inherent in Islamic views on income and wealth (Allheedan 2016). It is in the first place the responsibility of family members to support each other, the wider community only comes into view if dire poverty has to be averted and relatives are unable to offer sufficient support (Alwani 2016).

Muslim authors make much of zakat, in particular zakat mal, the obligatory wealth tax of Islam, as a means to combat poverty. An influential advocate of Islamic finance, Muhammad Nejatullah Siddiqi, calls zakat one of the two main pillars of Islam's economic system, the other one being the abolition of riba (Siddiqi 1983: 36). Yusuf al-Qaradawi calls it a unique institution and a measure of farreaching economic consequences:

"On the one hand it is a means of spiritual purification and on the other a way to regain balance and equilibrium in social and economic life (al-Qaradawi 2000, vol. I: i)." 


\section{THE ISLAMIC ECONOMY}

Others praise it as "a system through which a Muslim society can eradicate poverty and inequalities," while admitting that its potential is not fully exploited (Bashir et al. 2012; Bashir 2018). Zakat is, however, not a very fair tax. The assets subject to zakat make up a lower percentage of richer people's portfolio than of the poorer part of the population, in particular if the latter are working in agriculture or as artisans. That is because the set of zakatable items heavily draws on the Quran and the Hadith, that of course leave out products that did not yet exist at the time, while the application of analogy as a method in jurisprudence has not remedied the discrepancy. The fact that the fiqh scholars are far from unanimous on the set of zakatable items does not help either and offers wide scope for the well-heeled to take their obligations lightly (see on the complex discussions which assets are zakatable: Rehman, Ahmedov 2011; Sadeq 2002, or the brief survey in Visser 2019: chapter 3, section 3.3). Zakat is, furthermore, not a very effective tax because it only brings in low amounts of money. Figures from the Islamic Research and Training Institute (IRTI), a subsidiary of the Islamic Development Bank, for a couple of Muslim-majority countries do not exceed 0.3 per cent of GDP: zakat collected in Malaysia amounted to 0.24 per cent of GDP in 2011, 0.025 per cent of GDP in Indonesia in 2012 and 0.06 per cent of GDP in Pakistan in 2010-2011 (Islamic Social Finance Report 2014: 42), while in Sudan in 2013 it brought in 0.3 per cent of GDP (absolute sum in Islamic Social Finance Report 2015: 40 combined with GDP figure from World Bank). In Brunei Darussalam zakat collection fluctuated between 0.05 per cent and 0.12 per cent of GDP between 2001 and 2017 (Bashir et al. 2012). Moreover, zakat is not only used for helping the poor and people suffering from temporary misfortune, but also for dawah, that is, spreading the message of Islam, for the propagation of an Islamic way of life and for the people administering the zakat funds:

In fact the sadaqat [zakat] collection is for the poor, the helpless, those employed to administer the funds, those whose hearts need to be won over [to the truth], ransoming the captives, helping the destitute, in the Way of Allah and for the wayfarer. That is a duty enjoined by Allah; and Allah is All-Knowledgeable, Wise (Quran 9: 60). 
The distribution of the funds over the categories varies widely, not only between countries but also between regions within a country, but generally the poor and destitute receive much less than the full zakat receipts, the more so as collection costs can easily exceed ten per cent, in Sudan hovering around 20 per cent (figures in Islamic Social Finance Report 2014: 47; Islamic Social Finance Report 2015: 47). The glorification of zakat by fiqh scholars is another sign of their focus on the past. The sums needed in present-day societies for social purposes can only be brought in by taxes and social-security premiums. One can only agree with Muhammad Umer Chapra when he sees zakat not as a replacement for tax- and premium-funded social insurance but as a social self-help measure of the Muslim society to support the poor and destitute who for some reason fall through the social safety net (Chapra 1992: 274). It is to be noted that compliance with the obligation to pay zakat mal is low. It has been argued that much higher zakat collection levels should be possible, figures as high as $7.25 \%$ of GDP have been quoted in the case of Pakistan (Shaikh 2017). If this is correct, zakat could make a difference, even if it would still be insufficient to meet social expenditure on the scale required now.

In Islam there seems to be no urgent feeling that providing a minimum is perhaps not enough and that inequality in itself should not be exorbitant, though all Muslims and in particular the rich are encouraged to give generously above the obligatory zakat al-mal. One occasion is the annual eid al-fitr, or the Festival of Breaking the Fast, at the end of Ramadan, when Muslims are asked to give zakat alfitr for the benefit of the poor, or directly to the poor. Additional charity (sadaqah) is applauded; al-Qaradawi (2010: 102) quotes a saying of the prophet Muhammad:

I shall give alms to the poor again and again till each of them comes to possess at least one hundred camels (al-Qaradawi 2010: 102).

Still, it is only the genuinely poor whose poverty is not the result of their own negligence or unwillingness to look for work outside their own region who should be eligible for help, and even then it is first of all the duty of their relatives to provide assistance (al-Qaradawi 2010: 46ff). For all the quotes from the Hadith that 
fill the pages of publications by the likes of al-Qaradawi, the Islamic world, and especially the Middle East, cuts a relatively poor figure when it comes to income distribution. A study on incomes and income distribution in the Middle East shows that the region does worse than other regions in the world (Alvaredo et al. 2017). Admittedly, such figures should be interpreted with some caution, countries from the Middle East, and North Africa for that matter, do not cut such a poor figure if we look at Gini coefficients of income or consumption distribution - but on the other hand the rich may have all kinds of wealth and income items that stay below the radar of statistical bureaus (not only in the Middle East).

Top 1\% income share six regions, 2015, in per cent

Brazil 28

Middle East 26

India (2014) 22

USA 20

China 14

Western Europe 12

Note: distribution of pretax national income (before taxes and transfers, except pensions and unemployment insurance) among equal-split adults (income of households divided equally among adult members) (source: Alvaredo et al. 2017).

The argument here bore on the contention that zakat is an adequate instrument to combat poverty, and with widespread views on income distribution in the Islamic world. This is in no way meant as a judgement of individual charitable giving by Muslims, sadaqah. Still, the claim of those who flatly deny that there is any scarcity of natural resources and that Islam has already had achieved much in reducin poverty and exploitation sounds a bit hollow.

\section{Final comments}

It is one thing to extol the ethics of Islam, but it is unfair to compare the Islamic ideals with the practice of other thought systems or world views. Ideals of the one 
should be compared with ideals of the others and practices of the one with the practices of the others, and above all every society should compare its ideals with its own practices. There are few societies where the results will not be sobering. As for Islam, remember the conviction of Dr Asad Zaman that "Central to Islam is the spirit of service, and spending on others." Even if Islamic ethics were superior, Islamic behaviour is not. Quite a number of Muslim-majority countries score for instance very poorly on the 2018 Corruption Perception Index of Transparency International. Some countries do quite well: the United Arab Emirates scores rank 23, equal with Uruguay and just below the United States, Brunei Darussalam shares rank 31 with Taiwan, Qatar has rank 33, just above Israel, and all these countries score better than Spain and Italy. However, Malaysia, not exactly an underdeveloped failed state, scores a lowly rank 61, Tunisia and Morocco both 73, Turkey 78 and Kuwait 78, Indonesia 89, Egypt and Algeria both 105, Pakistan 117, Iran 138, Mauritania 144 and Afghanistan and Sudan 172 (Transparency International 2019; the list ranks 180 countries). Muslim-majority countries have little reason to look down on the ethical behaviour of non-Muslims. Farooq (2019) has every reason to find it extremely shameful that countries that call themselves an Islamic Republic and/or publicly profess to follow the sharia (Saudi Arabia, Pakistan, Iran, Mauritania, Sudan and Afghanistan) have such a poor score on the Corruption Perception Index.

Even more shameful are the human rights violations committed by a number of governments of Muslim-majority countries, including governments that actively support the spread of Islam and present themselves as modern, open societies (think oil-rich smaller Gulf states, see Fanack 2018). Now this can be seen as the cynical behaviour of political elites that do everything to stay in power. Quite another thing are the deep-seated convictions among the Muslim populace, based on their understanding of the sharia. According to research by Pew Research Center the percentage of the Muslim population that was in favour of stoning people who had committed adultery was over 80 in Egypt and Pakistan, 70 in Jordan, roughly 42 in Indonesia, some 23 in Lebanon and around 17 in Turkey ("The Economist" 2011). Non-Muslims should be pardoned for not feeling ethically inferior if they do not share such ideas. 


\section{THE ISLAMIC ECONOMY}

Not to remain in a negative mode, it cannot be denied that there are positive developments on the neglected issues. Environmental problems are slowly but surely receiving more attention from governments and the business community, just as in the rest of the world simply because they can no longer be neglected. Water management and renewable energy are getting more prominence, with the United Arab Emirates in the vanguard. Just as in Christianity, in Islam man is seen as God's steward or vice-regent, and Muslims can see it as a task assigned by God to take care of the earth (Quran 2: 30, 35: 39). So there is room for cooperation between Muslims and others on these issues - though the whole idea of mankind in a special position mandated to rule the earth has come under attack recently because it is held responsible for ruining the earth and for institutionalised cruelty to animals (Harari 2014: 465). Be that as it may, the identity politics of the Islamic world do not necessarily stand in the way of joint action, the Islamic Development Bank for instance wholeheartedly supports the Development Goals of the United Nations. Still, as Prof. Mahmoud El-Gamal noted,

The modus operandi of Islamic finance is worrisome for two reasons: it glorifies irrational adherence to outdated medieval jurisprudence, and supports the development of a separatist and boastful Islamic identity (El-Gamal 2007a).

El-Gamal would prefer cooperative forms of finance that meet ethical norms and sees no need for a separate specifically Islamic financial sector (El-Gamal 2007b). He tends to see Islamic finance first of all as a form of capitalist Islamism sponsored by the Gulf states and adopted by other states, all competing for petrodollars. He expects Islamic finance not to survive a drying-up of the stream of petrodollars (ElGamal 2019). However, the Islamic economy is more than Islamic finance, it is more and more an integrated whole of Islamic products and services that may bring a more uniform lifestyle to Muslim communities in different continents. The crumbling of the American-led post-second-world-war rule-based world order means that more tribal sentiments come to the fore; identity politics receive a boost and the Islamic economy is an important element in this process. 
A tricky question for an economist to answer is whether behind the tendency of the advocates of Islamic finance to rely on medieval fiqh scholars there does not lie a more fundamental question, a question that plagues all religions that rely on holy scriptures: how to square allegedly divine revelation from far more than a millennium ago with the exigencies of modern life and the results of centuries of scientific discoveries? Do all injunctions in the scriptures still apply now? Discussion of the nature of divine revelation and its application today can easily become dangerous in the Islamic world. Liberal reformers such as Fazlur Rahman (1919-1988), who had to flee Pakistan for the United States, found out the hard way that the more strict factions within Islam are strong enough to have deviations from traditional views on divine revelation declared anathema (see on Fazlur Rahman Birt 1996). The philologist Nasr Hamid Abu Zayd (1943-2010) was declared an apostate for similar reasons and saw himself forced to move from Egypt to the Netherlands (for his views on divine revelation, see Abu Zayd 2000). Earlier, Muhammad Abduh also met with fierce opposition. In Christianity by contrast, sixteenth-century Protestant reformers in Switzerland, in particular John Calvin (1509-1564), held that much of the divine revelation in the Old Testament (Tenach) applied specifically to the Jewish people living at that time and is not binding on later generations (Biéler 2005: 400-422). Such ideas are now widely accepted. And then, organized religion has largely lost its hold on society, in Western Europe at least, and increasingly also in the America's. In Islam there is the additional problem that the Hadith is assigned equal status with the Quran, while it is not obvious (to an outsider at least) that the prophet Muhammad's utterings on issues that were important in his time should be given equal status with God's supposedly immutable commands for later generations. It looks reasonable to reason that the prophet Muhammad accepted slavery, for instance, like St Paul did half a millennium earlier, simply because it was the normal thing in his time and not because of some divine instruction. Raising such questions is something many Muslims will not easily do, as rational analysis and research in matters of religion tends to be seen as tainted by waswas, flusterings of Shaytain, or Satan, meant to throw doubt in the minds of the believers about the truth of the Quran and the Hadith. Better to accept what the Prophet said unquestiongly and this, especially in the minds of Wahabites and other salafist, 


\section{THE ISLAMIC ECONOMY}

preferably as interpreted by medieval jurists such as Ibn Taymiyya (1263-1328). This attitude leads them to defend and even advocate such abominations as child brides, amputation of hands or feet, and beheading, crucifixion and stoning (according to Ibn Taymiyya, harsh punishments are an expression of God's mercy, as they help His worshippers remember His ordinances; even the condemned will accept the punishments if the ruler imposes them for the wellbeing of his subjects, Ibn Taymiyya 2019:169-170). Still, there are voices advocating a reinterpretation of the Quran and the Hadith taking into account the social and economic changes that have taken place since these were written down (M.A. Khan 2016). They refrain, though, from radical ideas on divine revelation.

It looks reasonable to expect the identity aspect to play a prominent role for a considerable period of time (see Hassan 2017: 2, quoted above). The umma wants to make its presence felt again and be taken seriously. This is fully understandable, but this goes hand in hand with the idea that Islamic ethical norms are superior. First, to a non-Muslim observer they are not, and second, there is a disconnect between the ideals and the real world. A problem for many Muslims themselves may be that if the development of the various sectors of an Islamic economy makes it possible to keep away from conventional providers, the pressure on them to conform to strict norms may increase and turn into coercion (see on bigotry among European Muslims Koopmans 2015). Group pressure is another aspect of Islam, or rather Islamic society, where non-Muslims can discern little of the alleged superiority of Islamic ethics.

\section{References}

Ahlborn M., Wortmann M. (2017), Output gap similarities in Europe. Detecting country groups, Center for European Governance and Economic Development Research Discussion Papers, no. 305, GeorgAugust Universität, Göttingen.

Abedifar P., Ebrahim S.M., Molyneux P., Tarazi A. (2015), Islamic Banking and finance. Recent empirical literature and directions for future research, "Journal of Economic Surveys", vol. 29 no. 4, pp. 637-670.

Abu Zayd N. (2000), The Qur'an: God and man in communication, inaugural lecture Cleveringa chair, Leiden University, http://www.let.leidenuniv.nl/forum/01_1/onderzoek/lecture.pdf [12.12.2019].

Ahmad M. (1999), Towards interest-free banking, Adam, Delhi. 
Alam Md. K., Ab Rahman S., Mustafa H., Mohammed Shah S., Hossain Md.S. (2019), Shariah governance framework of Islamic banks in Bangladesh. Practices, problems and recommendations, "Asian Economic and Financial Review", vol. 9 no. 1, pp. 118-132.

Allan M. (2019), Inleiding, in: Ahmad Ibn Taymiyya T.a.D., Bid, vecht en heers, Prometheus, Amsterdam, pp. 11-41.

Allheedan A. (2016), Poverty and wealth in Islam's sacred texts', chapter 14 in: Poverty and wealth in Judaism, Christianity, and Islam, Kollar N., Shafiq M. (eds.), Palgrave Macmillan, New York, pp. 263274.

al-Qaradawi Y. (2000), Fiqh al zakah, vol. I, King Abdulaziz University, Jeddah, http://iei.kau.edu.sa/Pages-E-EnglishPublications.aspx [12.12.2019].

al-Qaradawi Y. (2010), Economic security in Islam, Dar al Wahi Publication, Kuala Lumpur.

Alvaredo F., Assouad L., Piketty T. (2017), Measuring inequality in the Middle East 1990-2016. The world's most unequal region?, CEPR Discussion Paper No. DP12405.

Alwani Z. (2016), Socioeconomic and gender justice in the Qur'an. Modern challenges, chapter 5 in: Poverty and wealth in Judaism, Christianity, and Islam, Kollar N.R., Shafiq M. (eds.), Palgrave Macmillan, New York, pp. 77-103.

Amnesty International (2013), The dark side of migration. Spotlight on Qatar's construction sector ahead of the World Cup, https://www.amnesty.org/en/documents/MDE22/010/2013/en/ [12.12.2019].

Asutay M. (2012), The socio-ethical failure in Islamic banking and finance, "New Horizon”, no. 182.

Ayaz M., Mansoori M.T. (2017), Strengthening corporate governance regime for Islamic banks in Pakistan. Focusing on the principles of Amana and Mas'uliyah, "Journal of Islamic Business and Management", vol. 7 no. 2, pp. 178-196.

Ayub M. (2017), Liquidity management by Islamic banks. An issue or a contrivance for risk-free returns, "Journal of Islamic Business and Management", vol. 7 no. 1, pp. 8-19.

Ayub M., Paldi C. (2015), Dichotomy between Sharí'ah compliance and the economic goals of Islamic finance institutions, "Journal of Islamic Business and Management", vol. 5 no. 2, pp. 69-98.

Bashir Sharif M., Nur Annisa Haji Sarbini H., Abdullah H.R. (2012), Zakat management and capital assistances programme in Brunei Darussalam, "The Journal of Muamalat and Islamic Finance Research", vol. 9 no. 1, pp. 27-60.

Bashir A.-H. (2018), Reducing poverty and income inequalities. Current approaches and Islamic perspective, "JKAU Islamic Economics", vol. 31 no. 1, pp. 93-104.

Biéler A. (2005), Calvin's economic and social thought, WCC Publications, World Council of Churches, Geneva.

Birt Yahya M. (1996), The message of Fazlur Rahman, Association of Muslim Researchers, https://fazlur-rahman.livejournal.com/736.html [12.12.2019]. 


\section{THE ISLAMIC ECONOMY}

Cattelan V. (2018), Theoretical development and shortages of contemporary Islamic economics studies. Research programmes and the paradigm of shared prosperity, IKAM Reports 6/Research Papers 1, https://ssrn.com/abstract=3203696 [12.12.2019].

CBUAE (2010), Product details shariacompliant certificate of deposit (ICD), Central Bank of the UAE, www.centralbank.ae/en/pdf/notices/11-2010_2.pdf [12.12.2019].

Chapra M.U. (1992), Islam and the economic challenge, The International Institute of Islamic Thought, The Islamic Foundation, Hemdon, VA - Nairobi.

Damir-Geilsdorf, S. (2018), “...So that it may not circulate solely between the wealthy among you.". The critique of capitalism and the vision of a "balanced society" (mujtama " mutawāzin) in the writings of Sayyid Qutb (1906-1966), in: Muslims and capitalism. An uneasy relationship?, Hendrich B. (ed.), Ergon Verlag, Baden-Baden, pp. 173-89.

de Bellaigue Ch. (2018), The Islamic enlightenment. The modern struggle between faith and reason, Vintage, London.

Ebrahim M.S., Sheikh M. (2018), The political economy and underdevelopment of the Muslim world. A juridico-philosophical perspective, “Arab Law Quarterly”, vol. 32 no. 4, pp. 385-412.

Egger V.O. (2018), A history of the Muslim world since 1260. The making of a global community, 2nd ed., Routledge, New York - London.

El-Gamal M.A. (2006), Islamic finance. Law, economics, and practice, Cambridge University Press, New York.

El-Gamal M.A. (2007a), Incoherent pietism and Sharia arbitrage, "Financial Times", 23 May.

El-Gamal M.A. (2007b), Mutualization of Islamic banks, in: Handbook of Islamic banking, Kabir Hassan M., Lewis M.K. (eds.), Edward Elgar, Cheltenham, UK - Northampton, MA, USA, pp. 310-324.

El-Gamal M.A (2019), "Islamic finance" after state-sponsored capitalist-islamism, in: Islamaic finance. Between religious norms and legal practice, Decock W., Sagaert V. (eds.), Intersentia, Cambridge, UK, pp. 109-124.

Fanack (2018), In the United Arab Emirates, human rights under attack, https://fanack.com/united-arabemirates/human-rights/human-rights-under-attack, 3 August [12.12.2019].

Farooq M.O. (2012), Exploitation, profit and the riba-interest reductionism, "International Journal of Islamic and Middle Eastern Finance and Management”, vol. 5 no. 4, pp. 292-320.

Farooq M.O. (2019), Rent-seeking behaviour and zulm (injustice/exploitation) beyond ribā-interest equation, "ISRA International Journal of Islamic Finance", vol. 11 no. 1, pp. 110-123.

Gafoor A.L.M.A. (1996), Interest-free commercial banking, A.S. Noordeen, Kuala Lumpur.

Galbraith J.K. (1963), American capitalism. The concept of countervailing power, 2nd ed., Penguin, Harmondsworth. 
Garnier S. (2018), Review of Amira K. Bennison (2016), The Almoravid and Almohad empires, Edinburgh University Press, Edinburgh, "Studia Islamica", vol. 113 no. 1, pp. 97-103.

Ghazanfar S.M., Azim Islahi A. (1990), Economic thought of an Arab scholastic: Abu Hamid al-Ghazali (A.H. 450-505/A.D. 1058-1111), "History of Political Economy", vol. 22 no. 2, pp. 381-403.

Ghazanfar S.M., Azim Islahi A. (2011), Economic thought of Al-Ghazali, King Abdulaziz University Press, Jeddah.

Golestani T.A. (2018), Shi'i Islamic perspective on finance (Foundations of the Islamic economical system), "New Horizon", no. 199, pp. 25-30.

Harari Y.N. (2014), Sapiens. A brief history of humankind, Vintage, London.

Hashmi S.H. (2004a), Abduh, Muhammad (1849-1905), in: Encyclopedia of Islam and the Muslim world, Martin R.C. (ed.), Macmillan Reference USA, New York, pp. 6-7.

Hashmi S.H. (2004b), Qutb, Sayyid (1906-1966), in: Encyclopedia of Islam and the Muslim world, Martin R.C. (ed.), Macmillan Reference USA, New York, pp. 568-569.

Hashmi S.H. (2004c), Rida, Rashid (1865-1935), in: Encyclopedia of Islam and the Muslim world, Martin R.C. (ed.), Macmillan Reference USA, New York, p. 597.

Hallaq W.B. (1984), Was the gate of Ijtihad closed?, "International Journal of Middle East Studies”, vol. 16 no. 1 , pp. 3-41.

Hassan M.K. (2017), Introduction. Empirical research on Islam and economic life, in: Handbook of empirical research on Islam and economic life, Kabir Hassan M. (ed.), Edward Elgar, Cheltenham, pp. $1-19$.

Ibn Taymiyya T. al-Din A. (2019), Bid, vecht en heers, Prometheus, Amsterdam.

IFN Alerts (2016), UN Global Compact lacks Islamic banking participation, islamicfinancenews@ @redmoneygroup.com, 21 February [12.12.2019].

IFN Alerts (2017), Dubai Declaration on sustainable finance welcomes first and only fully-fledged Islamic financial institution, islamicfinancenews@ redmoneygroup.com, 1 September [12.12.2019].

Islamic Social Finance Report 2014 (2014), Islamic Research and Training Institute (IRTI) with the cooperation of Thomson Reuters, Jeddah.

Islamic Social Finance Report 1436H 2015 (2015), Jeddah: Islamic Research and Training Institute (IRTI) with the cooperation of Thomson Reuters.

Khan M.A. (2016), Reconstruction of Islamic economic thought. Need for innovative thinking (Ijtihad), working paper, https://ssrn.com/abstract=2892074 [12.12.2019].

Khan A.Q., Ali Bhatti A. (2018), Islamic banking and finance. A new paradigm in international relations, "Journal of Islamic Business and Management", vol. 8 no. 1, pp. 85-101. 


\section{THE ISLAMIC ECONOMY}

Khan T., Mohomed A.B.R.N. (2017), Ethical banking and Islamic banking. A comparison of Triodos Bank and Islami Bank Bangladesh Limited, "Islamic Economic Studies", 25 Special Issue, April, pp. 111-154.

Khan M.M., Usman M. (2016), Corporate social responsibility in Islamic banks in Pakistan, "Journal of Islamic Business and Management”, vol. 6 no. 2, pp. 179-190.

Koopmans R. (2015), Religious fundamentalism and hostility against outgroups. A comparison of Muslims and Christians in Western Europe, "Journal of Ethnic and Migration Studies", vol. 41 no. 1, pp. 33-57.

Kunhibava S., Tan Yen Ling S., Ruslan Md. K. (2018), Sustainable financing and enhancing the role of Islamic banks in Malaysia, "Arab Law Quarterly", vol. 32 no. 2, pp. 129-157.

Kuran T. (1995), Islamic economics and the Islamic subeconomy, "Journal of Economic Perspectives", vol. 9 no. 4 , pp. $155-173$.

Kuran T. (2004), Why the Middle East is economically underdeveloped. Historical mechanisms of institutional stagnation, "Journal of Economic Perspectives", vol. 18 no. 3, pp. 71-90.

Leins S. (2010), Zur Ethik des islamischen Finanzmarktes, „Zeitschrift für Wirtschafts- und Unternehmensethik“, vol. 11 no. 1, pp. 66-75.

Litardi I., Fiorani G., Harb D. (2019), Corporate social responsibility in Islamic culture. Comparison between Western CSR and Islamic CSR: focus on Islamic reporting initiative and Islamic financial institution, "European Journal of Islamic Finance", Special Issue Islamic and Social Finance, pp. 1-7.

Marx K., Engels F. (1890/1974), Manifest der Konnunistischen Partei, in: Marx K., Engels F., Ausgewählte Schriften in zwei Bänden, Dietz Verlag, Berlin.

Maududi S.A. A'la (1941/1999), The economic problem of man and its Islamic solution, address delivered at the Muslim University, Aligarh, 20 October, in: Maududi S.A.A'la, Economic system of Islam, 4th ed., Ahmad K. (ed.), Husain R. (trans.), Islamic Publications, Lahore, pp. 8-36.

Maududi S.A. A'la (1963), Economic and political teachings of the Qur'an, in: Sharf M.M. (ed.), A history of Muslim philosophy, vol. 1, Otto Harrassowitz, Wiesbaden.

Maududi S.A. A'la (1999), Economic system of Islam, 4th ed., Ahmad K. (ed.), Husain R. (trans.), Islamic Publications, Lahore.

Mukmimin K. (2018), How close Islamic banks are to global fraud. Learnings from Dubai Islamic Bank in the time of sub-prime crisis, "EJIF - European Journal of Islamic Finance", no. 11.

Opwis F. (2017), New trends in Islamic legal theory. Maqāṣid al-Sharī'a as a new source of law?, "Die Welt des Islams", vol. 57 no. 1, pp. 7-32.

Pathan R. (2016), Environmental, social and governance (ESG) investing strategies in Islamic funds, Islamic Commercial Law Report 2017, Thomson Reuters, pp. 146-148.

Quran (2004), The Qur'an in English translation, adapted and presented by MidEastWeb for Coexistence, www .mideastweb.org [12.12.2019]. 
Qureshi A.I. (1946), Islam and the theory of interest, Shaikh Muhammad Ashraf, Lahore.

Qutb S. (2000), Social justice in Islam, Hardie J.B. (trans.), Islamic Publications International, Oneonta, NY.

Rahman F. (1964), Riba and interest, "Islamic Studies (Karachi)”, vol. 3 no. 1, pp. 1-43.

Reda L. (2016), International labour standards and Islamic teachings. The principles of the basic entitlement package for migrant workers in Arab countries, "Arab Law Quarterly", vol. 30 no. 3, pp. 199-223.

Rehman J., Ahmedov A. (2011), Islamic law of obligatory Alms (Zakat). A teaching and learning manual, UK Centre for Legal Education, University of Warwick, Coventry, https://www.heacademy.ac.uk/system/files/introduction_to_welfare_and_zakat_law_in_islam.pdf [12.12.2019].

Rodinson M. (2014), Islam et capitalisme, Éditions Demopolis, Paris.

Rubin J. (2017), Rulers, religion, and riches. Why the West got rich and the Middle East did not, Cambridge University Press, New York.

Sadeq A.Al-Hasan (2002), A survey of the institution of Zakah. Issues, theories and administration, Discussion Paper No. 11, 2nd ed., Islamic Research and Training Institute, Islamic Development Bank, Jedda.

Sairally B.S. (2013), Evaluating the corporate social performance of Islamic financial institutions: an empirical study, "International Journal of Islamic and Middle Eastern Finance and Management", vol. 6 no. 3 , pp. $238-260$.

San-Jose L., Cuesta J. (2019), Are Islamic banks different? The application of the Radical Affinity Index, "International Journal of Islamic and Middle Eastern Finance and Management", vol. 12 no. 1, pp. 2-29.

Schacht J. (1982), An introduction to Islamic law, Oxford University Press, Oxford.

Shaikh S.A. (2017), Welfare potential of Zakat. An attempt to estimate economy wide Zakat Collection in Pakistan, "Journal of Islamic Economics, Banking and Finance", vol. 13 no. 1, pp. 52-70.

Slomp J. (2003), The "political equation" in Al-jihad fi al-Islam of Abul A'la Mawdudi (1903-1979), in: A faithful presence. Essays for Kenneth Cragg, Thomas D., Amos C. (eds.), Melisende, London, pp. 237-255.

Soo S. (2017), Recent developments in Islamic capital markets - green Sukuk, IFN Annual Guide 2018, pp. 18-20.

Suharto U. (2018), Riba and interest in Islamic finance. Semantic and terminological 1ssue, "International Journal of Islamic and Middle Eastern Finance and Management", vol. 11 no. 1, pp. 131138.

“The Economist" (2011), Pakistan: A great deal of ruin in a nation, April 2.

"The Economist" (2016), Migrant workers in the UAE, April 9. 


\section{THE ISLAMIC ECONOMY}

"The Economist" (2019), The new censors. The global gag on free speech is tightening, August 17.

Thomson Reuters (2017), Outpacing the mainstream. State of the Global Islamic Economy Report 2017/18, SalaamGateway.com [12.12.2019].

Thomson Reuters (2018), Islamic Finance Development Report 2018, https://ceif.iba.edu.pk/pdf/ReutersIslamic-finance-development-report2018.pdf [12.12.2019].

Transparency International (2019), Corruption Perception Index 2018, www.tranparency.org [12.12.2019].

Umar S. (2015), Commodity Murabahah / Tawarruq. Why regulators must stop its use', in: Islamic Commercial Law Report 2016, ISRA, Thomson Reuters, pp. 64-67.

Visser H. (2019), Islamic finance. Principles and practice, 3rd ed., Edward Elgar, Cheltenham, UK Northampton, MA.

Widhiyoga G. (2019), The construction of the Umma. From global consciousness to an aspirational global society, "The Muslim World", vol. 109 no. 3, pp. 209-223.

Wilson R. (2008), Development and spread of Islamic banking, “Orient”, vol. 49 no. III, pp. 12-24.

Zainuldin M.H., Kiat Lui T., Yii K.J. (2018), Principal-agent relationship issues in Islamic banks. A view of Islamic ethical system, "International Journal of Islamic and Middle Eastern Finance and Management”, vol. 11 no. 2, pp. 297-311.

Zaman A. (2015), Building genuine Islamic financial institutions, "Journal of Islamic Economics, Banking and Finance", vol. 11 no. 2, pp. 13-31.

Zaman R. (2011), Riba and interest in Islamic banking. An historical review, chapter 12: in: The foundations of Islamic banking. Theory, practice and education, Ariff M., Iqbal M. (eds.), Edward Elgar, Cheltenham. 